Index to the Palace of Minos

By Dr. Joan Evans. With Special Sections classified in detail and chronologically arranged, by Sir Arthur Evans. Pp. vi+221. (London : Macmillan and Co., Ltd., 1936.) 31s. $6 d$. net.

Publication of an index in a volume separate from the main work would not in the ordinary course call for special comment, beyond note of the fact of issue. The index of "The Palace of Knossos" stands in a different category. The fact that the history of the Palace, as reconstructed in Sir Arthur's excavations, covers the whole of the Minoan age, and the scale in range and detail on which the index has been compiled, not only make it an indispensable aid to the use of the book, of which it is an appendage, but also constitute it a guide to the history of the period and its civilization at large.

Even that, however, does not exhaust its claim to be an essential tool of the historian and the archæologist. The appearance of Sir Arthur's name as joint author is no mere formality ; and for certain entire headings, distinguished by his initials, he has been entirely responsible. As these headings are all of first-rate importance in the archæological and cultural sense, no one will quarrel with the author for having departed from the strict canons of the indexer. He has made each of them a chronological summary and survey of the subject with which it deals. The amount of detail which has thus been included may be judged from the fact that the entry for "pottery" runs to twenty-three pages, and many other heads of importance are treated on a like scale. The author's modest suggestion that the index may serve as a guide for those students who cannot afford the whole work does less than justice to its value and utility.

With a Spade on Stane Street

By S. E. Winbolt. Pp. xi $+240+12$ plates. (London : Methuen and Co., Ltd., 1936.) 10s. 6d. net.

StaNe Street, the Roman road running from Chichester to London, presents numerous problems, some of which have given rise to much controversy. The literature relating to it, in consequence, is considerable. Mr. Winbolt's contribution, however, cannot be regarded as in any way superfluous. Not only does he trace the road, field by field, in all its stages, but also he has submitted new and doubtful solutions for determining the line to the test of archæological excavation, where the application of this method has been possible. His verdict, therefore, may be taken as final. It is unfortunate that excavation has been possible at two only of the mansiones, or road-side stations. At Ewell, between which town and London the road is usually regarded as non-existent, the author has boldly attempted a reconstruction of the Roman town upon lines which, while purely conjectural, are supported by cogent argument. Mr. Winbolt is a strong supporter of an early date for the road, and maintains that its importance was due not to military exigencies, but to its use for public and commercial purposes.

\section{Organische Synthesen (Organic Syntheses)}

Übersetzt und für deutsche Verhältnisse bearbeitet von Dr. Richard Asmus. Pp. xii +586 . (Braunschweig: Friedr. Vieweg und Sohn, 1937.) 45 gold marks.

IN the collected volume (1932) of the first nine annual volumes of "Organic Syntheses" (1921-31), several improvements were incorporated. New processes for several compounds were included, the descriptions of experimental procedure were enriched with small but important improvements, and indexes to reactions, substances and processes were provided. Such small but highly useful improvements as the statement of amounts of corrosive liquids and solvents in cubic centimetres as well as grams made a considerable difference in the practical utility of the volume. The descriptions are very full and references are given to the literature.

In the German translation the American materials and apparatus have been replaced by those obtainable from German firms and any necessary modifcations of procedure introduced. By co-operation with the American editor-in-chief, Prof. Gilman, improved methods and corrections not to be found in the American edition have been introduced. The German edition will therefore be of interest to those who already possess the American volume, and it should prove most valuable to chemists who are more familiar with German than English. The paper and printing are good, and the translation appears to be careful and accurate.

\section{The Future of Woman}

By Anthony M. Ludovici. (To-day, To-morrow and After Series.) Pp. viii + 152. (London: Kegan Paul and Co., Ltd., 1936.) 3s. $6 d$. net.

THIs little book forms a supplement to the author's "Lysistrata", which he now regards as too mild an indictment of feminism. As in his previous works, he maintains that one of the first and principal steps in the regeneration of the Western world is a masculine renaissance of man both as animal and as spirit. Feminism he regards as "nothing more than a government of odd people, by odd people, for odd people". In conclusion, he declares that there can be no solution of life's problems for normal women which leads them away from their normal function of nursing and training children.

\section{Essentials of Modern Medical Treatment}

By Dr. Vincent Norman. Pp. xvi +200 . (London : Hutchinson's Scientific and Technical Publications, 1936.) 10s. $6 d$.

Considerably smaller and less comprehensive than the well-known "Index of Treatment", to which numerous specialists have contributed, this volume, which is the work of a single author, is to be recom. mended to the practitioner and student for its lucidity, conciseness and up-to-date character, as well as for its considerably lower price. In addition to the eminently practical advice on treatment, a short account is given of the causation and symptoms of the various diseases. 